\title{
ANALISIS MOTIVASI KEHADIRAN MAHASISWA FAKULTAS EKONOMI UNIVERSITAS ISLAM INDONESIA (PENDEKATAN TEORI PENGHARAPAN)
}

\author{
Suhartini \\ Fakultas Ekonomi \\ Universitas Islam Indonesia Yogyakarta \\ Romy Gustiansyah \\ Alumni Fakultas Ekonomi \\ Universitas Islam Indonesia Yogyakarta
}

\begin{abstract}
ABSTRAK
This Research reports the level of student's attendance motivation at Economic Faculty of Indonesian Islamic University by using the expectancy theory model. There are three variables of expectancy theory that use to measure the attendance motivation ( $Y$ ) according $E$. Lawler: efforts $\rightarrow$ attendance (X1), attendance $\rightarrow$ outcome (X2) and the valences of outcome (X3). This Research also reports which is the most dominant independent variables between $X 1, X 2$ and $X 3$ that influences the dependent variable $(Y)$ and also the influences of the different study program with attendance motivation level.

The first hypothesis is: the valence of outcome is the most dominant variable that influences the attendance motivation level. The second one is: there are any different at attendance motivation level based on their study program. The results show that student's attendance motivation at Economic Faculty of Indonesian Islamic University is high enough. The most dominant independent variable is effort $\rightarrow$ attendance and there are any different at attendance motivation level based on their study program. Specially at IESP student which have lower attendance motivation level than Management and Accountancy student.
\end{abstract}

Keywords: Motivate, Expectation, efforts $\rightarrow$ attendance, attendance $\rightarrow$ outcome and the valences of outcome

\section{PENDAHULUAN}

Menjelang terbentuknya dunia global dengan persaingan dan perubahan yang semakin tidak terduga, kualitas individual sumber daya manusia (SDM) suatu bangsa akan menjadi salah satu variabel yang menentukan kemampuan suatu bangsa dalam memenangkan persaingan dan menghadapi perubahan tersebut. Karenanya, peran institusi pendidikan sebagai sebuah organisasi yang mengolah input SDM menjadi SDM berkualitas menjadi sangat penting. Universitas Islam Indonesia (UII) sebagai salah satu institusi pendidikan tinggi swasta tertua telah mengambil peran tersebut sejak awal masa kemerdekaan, terutama Fakultas Ekonomi Universitas Islam Indonesia (FE-UII) yang merupakan fakultas tertua dalam lingkungan UII. 
Sebagai sebuah organisasi, dengan mahasiswa sebagai salah satu komponen utamanya, FE-UII menghadapi berbagai persoalan yang terkait dengan aspek formal maupun informal organisasi. Hal ini ditandai dengan beberapa kondisi umum mahasiswa UII (termasuk Fakultas Ekonomi) yang mengarah pada budaya pragmatisme, penurunan kedisiplinan, pergeseran nilai-nilai Islami yang tampak dari persepsi diri, gaya hidup, etika pergaulan serta minimnya keterlibatan mahasiswa dalam lembaga kemahasiswaan baik sebagai aktivis maupun partisipan. (Tim penyusun katalog UII, 2000, hal. 216).

Kondisi penurunan kedisiplinan mahasiswa akan lebih menjadi sorotan dalam penelitian ini, yaitu mengenai tingkat absensi mahasiswa FEUII dan persepsi mahasiswa FE-UII sendiri terhadap kehadiran mereka dalam mengikuti kegiatan perkuliahan. Ketidakhadiran mahasiswa dalam mengikuti kegiatan perkuliahan akan menghambat transfer ilmu pengetahuan pada FE-UII, sehingga akan menghambat pencapaian tujuan, visi dan misi organisasi secara menyeluruh. Dari pengambilan sampel terhadap 6 mata kuliah semester ganjil 2003/2004, kehadiran mahasiswa akan mempengaruhi tingkat prestasi akademik (nilai mata kuliah) yang mereka ambil tersebut. Sebanyak 44\% mahasiswa dengan kehadiran lebih dari $75 \%$ mendapatkan nilai $A$ atau $B$, sementara hanya $14 \%$ mahasiswa yang memperoleh nilai dibawah $B$. Untuk mahasiswa dengan kehadiran dibawah $75 \%$, sebanyak $12 \%$ memperoleh nilai A atau B, sisanya $30 \%$ memperoleh nilai dibawah $\mathrm{B}$.

Jika dikaitkan dengan kedisiplinan, manusia pada dasarnya bukanlah makhluk pemalas, dengan kata lain tidak ada satupun manusia pemalas di muka bumi ini, yang ada hanyalah manusia yang tidak termotivasi. Jika mendasarkan pada pernyataan diatas, pada dasarnya tidak ada mahasiswa yang malas untuk menghadiri kegiatan perkuliahan, yang ada hanyalah mahasiswa yang tidak termotivasi untuk hadir dalam kegiatan perkuliahan. Karenanya, upaya memotivasi mahasiswa untuk menghadiri kegiatan perkuliahan merupakan cara yang paling tepat dalam menekan tingkat absensi yang terjadi pada organisasi institusi pendidikan tinggi. Dengan kata lain, organisasi (baca: FE-UII) harus mampu menciptakan serangkaian kebijakan yang mampu memotivasi mahasiswa untuk menghadiri kegiatan perkuliahan.

Secara garis besar, teori motivasi dapat dibagi kedalam dua kelompok. Kelompok tersebut adalah teori proses (process theory) dan teori hasil (content theory). Teori proses menjelaskan mengenai "bagaimana" proses motivasi terjadi, sementara teori hasil mengabaikan proses terjadinya motivasi dan lebih menjelaskan mengenai "apa" yang memotivasi. Dengan kenyataan di atas, teori proses dianggap akan lebih mampu menjelaskan motivasi mahasiswa dalam menghadiri kegiatan perkuliahan. 
Salah satu teori motivasi proses yang pernah digunakan untuk menjelaskan motivasi kehadiran anggota organisasi adalah teori pengharapan atau expectancy theory. Teori ini dikemukakan oleh Victor Vroom pada tahun 1964 yang kemudian disempurnakan oleh. Lawler dan Porter pada tahun 1971. Penelitian mengenai motivasi kehadiran mahasiswa FE-UII ini menggunakan model teori pengharapan yang dikemukakan oleh Lawler dan Porter.

Dengan menggunakan model yang dikemukakan teori pengharapan Lawler dan Porter, tingkat motivasi kehadiran mahasiswa FE-UII akan diungkap untuk kemudian dapat diketahui variabel teori pengharapan mana yang paling dominan mempengaruhi tingkat motivasi kehadiran mahasiswa FE-UII. Selain itu juga, penelitian ini juga mengungkap pengaruh perbedaan jurusan (prodi) terhadap perbedaan tingkat motivasi kehadiran mahasiswa.

\section{KAJIAN PUSTAKA}

Penelitian mengenai permasalahan tingkat absensi menjadi obyek menarik dalam berbagai studi tentang bisnis dan organisasi di Amerika. Pada tahun 1975, penelitian yang dilakukan Yolles, Carone dan Krinsky yang dikutip oleh Richard M Steers dan Susan Rhodes (Usmara-editor, 2003, hlm. 49) menyebutkan lebih dari 400 juta hari kerja hilang di Amerika Serikat setiap tahunnya. Lawler, pada penelitian yang dilakukannya pada tahun 1971 menyebutkan ketidakhadiran karyawan mencapai 10\% - 20\% dari jumlah tenaga kerja yang ada. Sementara, penelitian yang dilakukan Lawler dan Mirvins (1977) menyimpulkan bahwa biaya ketidakhadiran karyawan non-manajerial adalah sebesar US \$ 66/hari termasuk gaji langsung, tunjangan, biaya pergantian dan biaya kerugian perusahaan (Steers \& Rhodes dalam Usmara - editor, 2003, hal. 49). Penelitian yang dilakukan tersebut menggunakan penekatan model teori proses dalam analisisnya Sementara, penelitian mengenai tingkat absensi di Indonesia dilakukan oleh Lenny Rikayanti (1997) pada RS PKU Muhammadiyah Yogyakarta yang menyimpulkan bahwa terdapat pengaruh negatif yang signifikansi antara kepuasan kerja dengan tingkat absensi karyawan. Penelitian Rikayanti yang menggunakan pendekatan teori hasil (content theory) juga menyimpulkan variabel kepuasan kerja finansial sebagai variabel yang dominan pengaruhnya terhadap tingkat absensi. Penelitian dengan obyek motivasi kehadiran dengan subyek mahasiswa pada FE-UII ini menggunakan model teori proses (teori pengharapan) dalam analisisnya.

Dalam perusahaan, ketidakhadiran karyawan akan menimbulkan berbagai biaya akibat ketidakhadiran karyawan termasuk keruguian yang akan terus terakumulasi. Dalam organisasi perguruan tinggi, ketidakhadiran mahasiswa akan menghambat transfer ilmu pengetahuan dan nilai-nilai 
organisasi kepada mahasiswa yang tentunya akan berpengaruh terhadap rendahnya performance mahasiswa secara individu. Hal ini tidak hanya tercermin dari indeks prestasi akademik (IP) mahasiswa bersangkutan, tapi juga termasuk kemampuan mereka untuk mengerjakan tugas akhir secara cepat dan mandiri sehingga tidak menghambat kelulusan. Banyaknya mahasiswa yang mengalami keterlambatan kelulusan merupakan salah satu indikator rendahnya performance organisasi. Sementara, banyaknya mahasiswa yang tidak mampu mengerjakan tugas akhir secara mandiri akan berimbas pada rendahnya kualitas lulusan. Akibatnya, mereka tidak mampu bersaing di dunia kerja, image perguruan tinggi akan menjadi negatif dimata masyarakat.

Gambar 1 memperlihatkan bagaimana aspek-aspek teori pengharapan mempengaruhi kehadiran mahasiswa yang berimbas kepada kinerja organisasional dan kepuasan individu atas apa yang mereka peroleh dari sebuah kehadiran.

\section{Gambar 1}

Pengaruh kehadiran terhadap Organisasi dan Individu

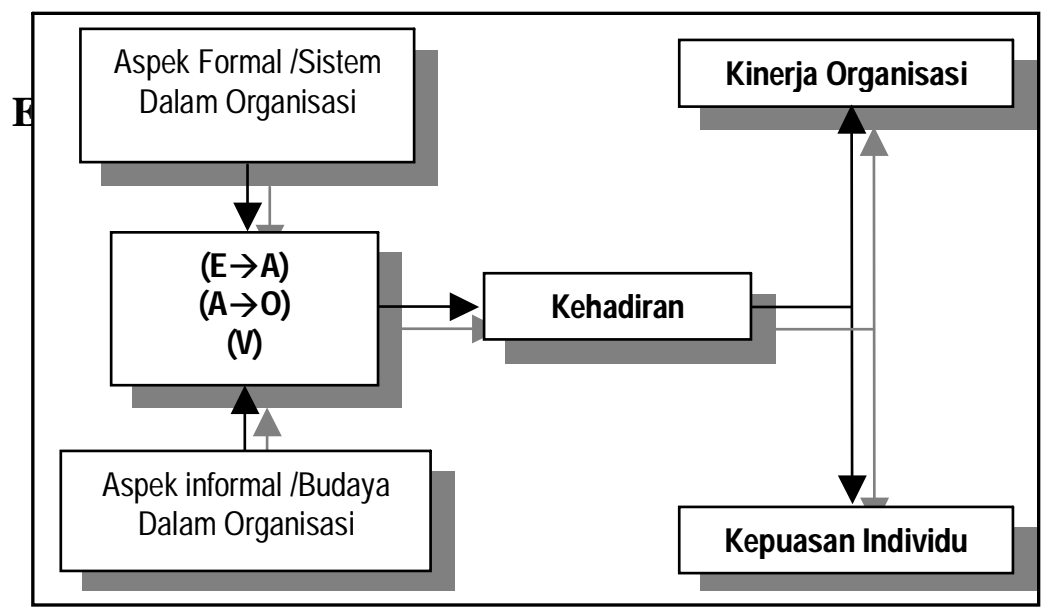

Sumber: Adaptasi dari Lawler dalam Kanungo dan Mendoca (1992)

Berbagai pengertian tentang motivasi banyak dikemukakan oleh para ahli manajemen, organisasi maupun psikologi. Menurut Victor Vroom:

"Motivasi sebagai suatu proses pengaturan pilihan diantara bentuk alternatif dari aktivitas sukarela. Dalam pandangannya, umumnya perilaku berada dalam kendali sukarela orang bersangkutan dan karenanya di motivasi." (dalam Gibson dkk, 1996, hlm. 242)

Ditinjau dari pengertian diatas, Vroom menganggap motivasi merupakan sesuatu yang berada pada alam sadar. Hal inilah yang menjadi 
kelemahan utama teori pengharapan, teori ini tidak mampu menjelaskan motivasi yang berasal dari alam bawah sadar manusia. Namun, diluar kelemahan tersebut, teori pengharapan merupakan teori yang dipandang paling baik menjelaskan motivasi seseorang dalam lingkungan organisasionalnya (Siagian, 1995, hlm. 179). Teori pengharapan merupakan model yang rumit dipahami dan diterapkan (Gibson dkk., 1996, hlm 248), namun variabel-variabel yang terdapat didalamnya mencakup proses bagaimana sebuah motivasi terbentuk dimulai dari kemampuan melakukan sebuah pekerjaan, keyakinan akan perolehan suatu outcome hingga value outcome tersebut bagi seorang individu. Tidak hanya itu, Kanungo dan Mendoca menjelaskan bahwa model teori pengharapan menyediakan kerangka berfikir konseptual yang bermanfaat dalam menjelaskan motivasi kehadiran (Kanungo \& Mendoca, 1992, hlm.159). Pengertian teori pengharapan sendiri menurut Victor Vroom adalah:

"Teori dimana seseorang dihadapkan pada satu set hasil tingkat pertama dan memilih suatu hasil yang didasarkan pada bagaimana pilihan tersebut dihubungkan dengan hasil tingkat kedua. Preferensi individu didasarkan kepada kekuatan (valensi) dari keinginan untuk mencapai posisi tingkat kedua dan persepsi hubungan antara hasil tingkat pertama dan kedua." (dalam Gibson dkk., 1996 hlm. 242).

Setiap teori pasti memiliki asumsi, beberapa asumsi mengenai teori pengharapan Lawler (Nadler dan Lawler dalam Usmara-Editor, 2003, 15) adalah:

1. Perilaku ditentukan oleh kombinasi antara kekuatan yang berasal dari dalam individu dengan kekuatan yang berasal dari lingkungan

2. Karyawan (Mahasiswa) mengambil keputusan tentang perilakunya sendiri dalam organisasi.

3. Masing-masing orang memiliki jenis kebutuhan, keinginan dan tujuan berbeda.

4. Orang membuat keputusan dari alternatif rencana-rencana perilaku yang didasarkan pada persepsi (pengharapan) mengenai tingkatan sampai dimana perilaku tertentu mengarah ke hasil yang diinginkan.

Asumsi-asumsi dari teori pengharapan diatas terbentuk oleh kenyataan asumsi-asumsi teori hasil yang sangat susah untuk diwujudkan. Beberapa asumsi teori hasil tersebut: anggapan bahwa semua karyawan sama, semua situasi sama dan hanya ada satu cara terbaik dalam memotivasi. (Nadler \& Lawler dalam Usmara - ed, 2003, hlm. 14). Ketiga asumsi tersebut adalah situasi yang sangat sulit untuk diwujudkan. Karenanya, teori pengharapan memiliki asumsi-asumsi teori yang lebih mungkin diwujudkan situasinya. 
Berdasar pada teori yang dikemukakan oleh Vroom pada tahun 1964, Lawler dan Porter menyusun sebuah model teori pengharapan dengan tiga variabel utama, yaitu: effort $\rightarrow$ performance (attendance); performance (attendance) $\rightarrow$ Outcome dan the valence. Dari ketiga variabel tersebut, maka motivasi kehadiran seorang mahasiswa akan menjadi tinggi apabila:

1. Mahasiswa percaya mereka mampu untuk memenuhi kehadiran dikelas (effort $\rightarrow$ attendance).

2. Mahasiswa percaya bahwa kehadiran akan mengarah kepada suatu hasil tertentu (attendance $\rightarrow$ outcome)

3. Mahasiswa percaya bahwa hasil tertentu tersebut memberi value positif bagi mereka. (The valence).

Model umum dari teori pengharapan yang dikemukakan Nadler dan Lawler (Nadler \& Lawler dalam Usmara - ed., 2003, hlm. 19) adalah:

\section{Gambar 2}

Rangkaian Model Umum Lawler

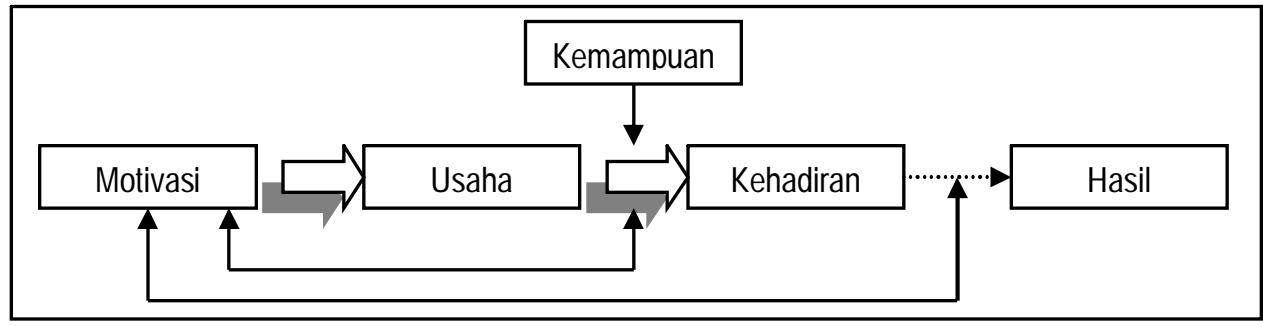

Sumber : Nadler dan Lawler dalam Usmara (ed) (2003), hlm. 19

Effort $\rightarrow$ Attendance merupakan modifikasi dari variabel Effort $\rightarrow$ Performance. Selain itu komponen ini juga lazim disebut Actual Situation, pengertiannya adalah mengenai situasi aktual yang dirasakan oleh seseorang tentang dirinya, tentang pertanyaan "mampukah saya?" atau dalam kaitannya dengan kehadiran adalah merupakan pertanyaan "Mampukah saya hadir?"

Variabel Attendance $\rightarrow$ Outcome merupakan hasil modifikasi dari Performance $\rightarrow$ Outcomes ini mencoba menjelaskan mengenai arah perilaku menuju kepada sebuah hasil tertentu yang akan diperoleh dari sebuah perilaku. Komponen variabel ini juga sering disebut actual situation and communication from others. Dalam hal ini, seorang individu akan melihat actual situation (Dalam hal ini dicontohkan sebagai kemungkinan kepuasan karyawan, dan akibat dari kondisi pasar tenaga kerja, sanksi ketidak hadiran dan kebijakan perusahaan) yang diserta communication from others (Norma kelompok). 
Ketika diadaptasi kedalam subjek mahasiswa, variabel ini mencoba menjelaskan mengenai persepsi yang terbentuk atas hasil yang mereka peroleh dari sebuah kehadiran. Dalam kasus ini digunakan parameter instrinsik (content kuliah) dan ekstrinsik (context kuliah). Parameter Instrinsik dari sebuah perkuliahan ketika dikaitkan dengan persepsi akan kemungkinan outcomes yang akan mereka peroleh dari sebuah kehadiran secara instrinsik, yaitu: mata kuliah itu sendiri, kesempatan untuk memperoleh pengetahuan lebih dan perasaan aktualisasi diri melalui kehadiran. Parameter ekstrinsik dari sebuah perkuliahan meliputi Outcomes yang mereka peroleh dari sebuah kehadiran secara ekstrinsik (context), yaitu: nilai dari mata kuliah tersebut, permasalahan dosen, rekan sekelas serta ruangan tempat belajar.

Valence merupakan nilai yang dirasakan oleh seorang individu atas Outcomes yang mereka peroleh dari sebuah kehadiran. Valence ini bersifat respon terhadap sesuatu sehingga bisa menjadi positif, negatif maupun netral. Selain itu, valence juag sering disebut dengan instrumentalis, karena mencoba menjelaskan daya tarik sebuah outcome terhadap anggota organisasi, dalam hal ini adalah mahasiswa. Munculnya perbedaan respon individu terhadap sebuah outcome dapat merupakan akibat dari permasalahan perbedaan etos kerja serta loyalitas dan komitmen terhadap organisasi yang berbeda-beda pada setiap individu Dalam hal ini, etos kerja lebih luas dapat diartikan sebagai budaya organisasi. Ketika sebuah organisasi tidak mampu menanamkan budaya organisasi pada masing-masing individu, maka budaya organisasi tidak akan terbentuk dan mendukung kebutuhan organisasi. Setiap individu mungkin tidak merasa menjadi bagian dari sebuah organisasi, akibatnya respon negatif terhadap outcomes dari sebuah perilaku akan cenderung negatif. Namun, apabila organisasi mampu menumbuhkan budaya organisasi yang sesuai dengan kebutuhan organisasi, respon positif terhadap outcomes akan lebih mungkin terjadi.

Ketiga variabel tersebut membentuk sebuah persamaan yang dikenal dengan model harapan Lawler. Hubungan ketiga variabel tersebut adalah:

$\{(E \rightarrow A) \times(A \rightarrow O) \times($ Valence $)\}=$ Motivation Force

Dalam penjelasan secara kualitatif, teori pengharapan "dilenturkan" dengan melibatkan teori-teori motivasi lainnya. Dalam penjelasan mengenai aktualisasi diri mahasiswa, teori hirarkhi kebutuhan Maslow digunakan sebagai teori yang membantu menjelaskan aktualisasi tersebut. Begitu juga dengan permasalahan afiliasi dengan rekan-rekan sekelas dalam kegiatan perkuliahan, need of affiliation dalam teori 3 kebutuhan Mc. 
Clelland digunakan sebagai salah satu komponen sub-variabel. Lebih jauh lagi, pada variabel attendance $\rightarrow$ outcome, outcome dibagi atas content dari kuliah dan context dari kuliah, dimana pembagian ini didasarkan pada teori dikotomi Herzberg. Terdapat dua hipotesa yang akan dibuktikan dalam penelitian ini, yaitu:

1. Variabel teori pengarapan yang berupa the valence dari outcomes adalah faktor yang paling berpengaruh terhadap motivasi mahasiswa dalam menghadiri kuliah.

2. Berdasarkan pada jurusan, terdapat perbedaan tingkat motivasi mahasiswa dalam menghadiri kuliah.

\section{METODE PENELITIAN}

Dalam mengungkap motivasi kehadiran yang merupakan sebuah konstruk pesikologis, peneliti menggunakan data kuantitatif dan data kualitatif sebagai dasar analisis masalah, termasuk penggunaan berbagai teori pendukung dan bantuan subyek lain selain mahasiswa sebagai sumber data kualitatif.

Dalam menganalisa motivasi kehadiran, digunakan teknik sampling dengan metode Proportioned Stratified Sampling (Sampling bertingkat proporsional), dimana populasi dari sampel terdiri dari stratum-stratum, dalam hal ini terbagi atas elemen elemen angkatan dan jurusan yang merupakan sub-populasi cenderung homogen. Sub-Populasi didasarkan atas jurusan dan angkatan. Dimana populasi penelitian ini merupakan semua mahasiswa FE-UII yang aktif kuliah pada semester gasal 2003/2004, mahasiswa tersebut telah memilih mata kuliah sendiri dan belum mengambil KKN atau tugas akhir. Berdasarkan ciri tersebut, populasi penelitian ini adalah mahasiswa FE-UII angkatan 2001/2002 dan 2002/2003. Pembagian sampel terlihat pada tabel 3 .

Tabel 3

Populasi dan Sampel Mahasiswa FE-UII angkatan 2001 dan 2002

\begin{tabular}{|l|c|c|c|c|c|c|c|c|c|}
\hline \multirow{2}{*}{ Angkatan } & \multicolumn{3}{|c|}{ Manajemen } & \multicolumn{3}{c|}{ Akuntansi } & \multicolumn{3}{c|}{ IESP } \\
\cline { 2 - 11 } & Populasi & $\%$ & Sampel & Populasi & $\%$ & Sampel & Populasi & $\%$ & Sampel \\
\hline $2001 / 2002$ & 495 & $24 \%$ & 35 & 460 & $23 \%$ & 33 & 215 & $11 \%$ & 16 \\
\hline $2002 / 2003$ & 430 & $21 \%$ & 31 & 274 & $13 \%$ & 19 & 164 & $8 \%$ & 12 \\
\hline
\end{tabular}

Sumber : Bag. Pengajaran FE-UII tahun 2003/2004.

Variabel-variabel dalam teori pengharapan didefinisikan kedalam parameter-parameter untuk kemudian dijadikan pertanyaan-pertanyaan dalam kuisioner sebagai instrumen penelitian. Definisi operasional variabel dalam parameter-parameter adalah sebagai berikut: 
1. The Efforts $\rightarrow$ attendance expectancy $\left(\mathrm{X}_{1}\right)$

(i) Tingkat kesehatan fisik mahasiswa

- Tingkat penggunaan alkohol dan obat-obat terlarang

口 Penyakit yang dimiliki

口 Tingkat stress

(ii) Kegiatan lain diluar kuliah

- Tingkat kepentingan kegiatan mahasiswa diluar jam kuliah

(iii) Sarana transportasi

口 Jarak yang harus ditempuh menuju kekampus

- Ketersediaan alat transportasi

2. The Attendance $\rightarrow$ Outcomes Expectancy (X2)

(i) Content dari kuliah

口 Mata kuliah yang bersangkutan

- Kesempatan untuk mengaktualisasikan diri sebagai mahasiswa

口 Kemampuan lebih dalam memahami materi kuliah

(ii) Context dari kuliah

口 Nilai yang lebih baik.

口 Sosialisasi dengan teman-teman kuliah.

- Ruang kelas yang nyaman

- Kualitas dosen yang baik

3. The Valence of Outcomes (X3)

The valence dari outcomes akan terkait dengan ketertarikan mahasiswa terhadap outcomes yang mereka peroleh ketika menghadiri kuliah. Dalam mengukur motivasi kehadiran, outcomes terhadap kehadiran maupun outcomes terhadap absensi sebenarnya merupakan dua sisi dari fenomena yang sama. Artinya, keduanya akan sangat dipengaruhi oleh instrumen pemenuhan harapan mahasiswa. Oleh karena itu, pengukuran terhadap variabel ini didasarkan pada seberapa menarik outcomes yang diperoleh mahasiswa atas kehadiran mereka dalam mengikuti mata kuliah didasarkan pada persepsi masing-masing mahasiswa. Apabila tingkat ketertarikan terhadap outcomes tinggi dan positif, maka akan menambah motivasi mahasiswa yang bersangkutan, sebaliknya jika tingkat ketertarikannya negatif, maka tingkat motivasi untuk hadir akan menjadi negatif.

4. Motivasi Mahasiswa ( $Y$ )

Tingkat motivasi merupakan variabel terikat dalam penelitian ini. Tingkat motivasi mahasiswa tersebut diperoleh dari persamaan:

$$
\left\{X_{1} \times \Sigma\left(X_{2} \times X_{3}\right)\right\}=\text { Tingkat Motivasi Kehadiran }
$$

Secara kuantitatif, alat-alat analisis yang digunakan adalah:

\section{Model Lawler}


Lawler merupakan salah satu tokoh yang mengemukakan teori pengharapan selain dari Victor Vroom. Model teori pengharapan Lawler yaitu:

Dimana :

$$
\{(E \rightarrow A) \times \Sigma[(A \rightarrow O) \times(V)]\}=\text { Motivation Force }
$$

$(\mathrm{E} \rightarrow \mathrm{A})=$ Effort Attendance Expectancy $(\mathrm{X} 1)$

$(\mathrm{A} \rightarrow \mathrm{O})=$ Attendance Outcomes Expectancy $(\mathrm{X} 2)$

(V) = The Valence or Attractiveness of Outcomes (X3)

Pengukuran dilakukan melalui data kuisioner yang telah dikuantitatifkan. Skala yang digunakan adalah skala likert 5 pilihan jawaban dengan bobot seperti pada tabel 4 .:

\section{Tabel 4}

Bobot Kuisioner Penelitian

\begin{tabular}{|l|r|r|r|r|r|}
\hline \multicolumn{1}{|c|}{ Variabel } & STS & TS & KS/N & S & SS \\
\hline$(E \rightarrow A)$ & 0 & 0,25 & 0,5 & 0,75 & 1 \\
\hline$(A \rightarrow O)$ & 0 & 0,25 & 0,5 & 0,75 & 1 \\
\hline$(V)$ & -1 & $-0,5$ & 0 & 0,5 & 1 \\
\hline
\end{tabular}

2. Regresi Linier Berganda

Dengan menggunakan regresi linier berganda, akan diketahui variabel mana dari teori pengharapan yang paling dominan mempengaruhi motivasi kehadiran mahasiswa. Persamaan dasar regresi linier berganda (Umar, 1998, 188):

$$
Y=a+b X_{1}+c X_{2}+d X_{3}
$$

Y = Variabel terikat; $\quad$ a $=$ Konstanta

$X_{1}, X_{2} \& X_{3}=$ Variabel bebas; $\quad b, c$ \& $d=$ Koefisien Regresi

Variabel (signifikan) yang memiliki angka koefisien regresi paling tinggi merupakan variabel bebas yang paling dominan berpengaruh terhadap variabel terikat.

3. Metode Chi-square, Test Independensi

Uji chi-square adalah untuk melihat ada tidaknya perbedaan tingkat motivasi kehadiran mahasiswa pada jurusan yang berbeda. Adanya tujuan tersebut, sehingga hipotesis operasional untuk uji chi-square ini adalah: Ho = Tidak ada perbedaan tingkat motivasi kehadiran berdasar jurusan $\mathrm{H}_{1}=$ Terdapat perbedaan tingkat motivasi kehadiran berdasar jurusan

\section{ANALISA DATA DAN PEMBAHASAN}


Dengan menggunakan model teori pengharapan Lawler, diperoleh hasil yang menunjukkan bahwa setiap manusia (mahasiswa) berbeda dan memiliki tingkat motivasi yang berbeda satu sama lain. Untuk mempermudah pengambilan kesimpulan, maka dilakukan pengelompokan seperti pada tabel 5 berikut:

Tabel 5

Pembagian Kelas untuk Variabel Tingkat Motivasi

\begin{tabular}{|c|c|c|l|}
\hline \multicolumn{3}{|c|}{ Konstruk } & Keterangan \\
\hline-7 & s/d & -4.2 & Tidak termotivasi \\
\hline-4.2 & s/d & -1.4 & Kurang termotivasi \\
\hline-1.41 & s/d & 1.4 & motivasi rendah \\
\hline 1.41 & s/d & 4.2 & motivasi sedang \\
\hline 4.21 & s/d & 7 & motivasi tinggi \\
\hline
\end{tabular}

Dari hasil analisis model dengan menggunakan software Excel diperoleh hasil seperti pada tabel 6 .

Tabel 6

Distribusi Analisis Model Lawler yang sudah Dikelompokkan

\begin{tabular}{|l|c|c|}
\hline Jawaban & Frekuensi & Persentase \\
\hline Tidak ada Motivasi & 0 & $0.0 \%$ \\
\hline Kurang termotivasi & 0 & $0.0 \%$ \\
\hline Motivasi rendah & 39 & $26.7 \%$ \\
\hline Motivasi sedang & 102 & $69.9 \%$ \\
\hline Motivasi tinggi & 5 & $3.4 \%$ \\
\hline
\end{tabular}

Sumber: Data Primer dari sampel mahasiswa FE-UII tahun 2003/2004

Dari tabel 6, terlihat bahwa pada dasarnya semua responden memiliki motivasi untuk hadir. Hanya saja, motivasi tersebut tidaklah besar. Dari pengelompokkan kelas tersebut, hanya 5 responden $(3,4 \%)$ yang memiliki motivasi kehadiran tinggi. Angka terbesar pada tingkat motivasi sedang $(69,9 \%)$ dan sisanya sebanyak 39 responden $(26,7 \%)$ memiliki motivasi kehadiran yang rendah.

Motivasi kehadiran yang sedang masih memungkinkan mahasiswa untuk tidak menghadiri kuliah walaupun persentasenya kecil. Sementara itu, kelompok yang bermotivasi rendah sering kali tidak menghadiri kuliah walaupun mereka sebenarnya memiliki motivasi untuk hadir dalam kegiatan perkuliahan. 3,4\% responden yang memiliki motivasi tinggi dapat dipastikan bisa selalu hadir dalam setiap kegiatan perkuliahan.

Analisa regresi linier berganda ditujukan untuk mengetahui pengaruh variabel-variabel teori pengharapan terhadap motivasi kehadiran mahasiswa FE-UII untuk kemudian diketahui variabel teori pengharapan 
mana yang paling dominan pengaruhnya terhadap motivasi kehadiran mahasiswa FE-Ull seperti terlihat pada tabel 7.

Dari tabel 7 diketahui secara keseluruhan, semua variabel yang terdapat pada teori pengharapan mempengaruhi motivasi kehadiran mahasiswa FE-Ull. Hal ini terlihat dari angka R square adjust yang mencapai 0,903. Hal ini berarti 90,3\% tingkat motivasi kehadiran mahasiswa FE-UII dipengaruhi oleh variabel-variabel dalam teori pengharapan, sisanya sebesar $9,7 \%$ dijelaskan oleh variabel lain yang tidak disertakan dalam penelitian ini.

Tabel 7.

Angka Regresi Linier Berganda

\begin{tabular}{|l|r|r|r|}
\hline \multicolumn{1}{|c|}{ Variabel } & \multicolumn{1}{c|}{ B } & \multicolumn{1}{c|}{ t hitung } & \multicolumn{1}{c|}{ Sig. } \\
\hline Konstanta & -3.252 & $-16,291$ & 0,000 \\
\hline X1 & 2,816 & 9,343 & 0,000 \\
\hline X2 & 0,372 & 8,032 & 0,000 \\
\hline X3 & 0,39 & 18,869 & 0,000 \\
\hline R square adjust $=$ & 0,903 & \\
Alpha $=$ & 0,05
\end{tabular}

Sumber: Data Primer, diolah

Dari tabel 7 diketahui bahwa variabel effort $\rightarrow$ attendance memiliki koefisien tertinggi dibanding kedua variabel lainnya. Hal ini menunjukkan bahwa variabel $\mathrm{X}_{1}$ (effort $\rightarrow$ attendance) merupakan variabel yang paling dominan pengaruhnya terhadap tingkat motivasi kehadiran mahasiswa. Sehingga, hipotesa kedua yang menyatakan variabel the valence dari outcome sebagai variabel yang paling dominan pengaruhnya terhadap motivasi kehadiran mahasiswa FE-UII, tidak terbukti.

Sementara, hasil dari crosstab jurusan dan tingkat motivasi kehadiran mahasiswa diperoleh hasil seperti pada tabel 8.:

Tabel 8.

Hasil Crosstab Baris dan Kolom

\begin{tabular}{|l|c|c|c|c|c|c|c|c|c|c|}
\hline \multirow{2}{*}{ Responden } & \multicolumn{10}{|c|}{ Tingkat Motivasi } \\
\cline { 2 - 12 } & $\begin{array}{c}\text { Tidak } \\
\text { ada }\end{array}$ & $\%$ & Kurang & $\%$ & $\begin{array}{c}\text { Ren- } \\
\text { dah }\end{array}$ & $\%$ & $\begin{array}{c}\text { Se- } \\
\text { dang }\end{array}$ & $\%$ & Tinggi & $\%$ \\
\hline Manajemen & 0 & $0 \%$ & 0 & $0 \%$ & 11 & $16.7 \%$ & 52 & $78.8 \%$ & 3 & $4.5 \%$ \\
\hline IESP & 0 & $0 \%$ & 0 & $0 \%$ & 15 & $53.6 \%$ & 12 & $42.9 \%$ & 1 & $3.6 \%$ \\
\hline Akuntansi & 0 & $0 \%$ & 0 & $0 \%$ & 13 & $25.0 \%$ & 58 & $73.1 \%$ & 1 & $1.9 \%$ \\
\hline Total & 0 & & 0 & & 39 & & 122 & & 5 & \\
\hline
\end{tabular}

Pearson Chi Square $=14,451$ 
Sig. $\quad=0,006$

Sumber: Data Primer, Diolah

Dari tabel 8 diatas diperoleh angka chi squares sebesar 14,451 dengan signifikansi 0,006 . Pada tingkat toleransi kesalahan sebesar $5 \%$, Angka signifikansi yang lebih kecil dari 0,05 (5\% kesalahan) menyebabkan $\mathrm{Ho}$ ditolak dan $\mathrm{H}_{1}$ diterima. Karenanya, berdasarkan uji beda chi square diperoleh kesimpulan Bahwa terdapat perbedaan tingkat motivasi kehadiran mahasiswa berdasarkan jurusan. Dengan kata lain hipotesis kedua pada penelitian ini terbukti.

Dari tabel 6, terlihat bahwa untuk mahasiswa prodi Manajemen, sebanyak 78,8\% memiliki motivasi kehadiran sedang, 16,7\% memiliki motivasi kehadiran rendah dan sebesar 4,5\% memiliki motivasi kehadiran yang tinggi. Hal ini tidak jauh beda dengan mahasiswa prodi Akuntansi yang sebanyak $73,1 \%$ memiliki motivasi sedang dan $25 \%$ memiliki motivasi rendah, sementara 1,9\% mahasiswa memiliki motivasi tinggi. Yang terlihat berbeda adalah pada mahasiswa IESP. Sebanyak 53,6\% Mahasiswa IESP memiliki motivasi kehadiran yang rendah, 42,9\% memiliki motivasi kehadiran yang sedang dan sisanya 3,6\% memiliki motivasi kehadiran yang tinggi.

Dari paparan tabel 8, mahasiswa IESP masih memiliki motivasi kehadiran rendah cukup banyak (lebih dari separuh). Hal ini perlu mendapat perhatian khusus dari pihak fakultas, terutama prodi IESP. Kenyataan pada tabel diatas setidaknya menunjukkan terdapat permasalahan terselubung pada mahasiswa IESP, yaitu mengenai motivasi kehadiran mereka yang cenderung lebih rendah dibanding kedua prodi yang lainnya.

Sementara, mengenai angka kehadiran mahasiswa sebenarnya, diperoleh data seperti terlihat pada tabel 9 :

Tabel 9

Angka Kehadiran Mahasiswa FE-UII pada Semester Ganjil 2003/2004

\begin{tabular}{|l|c|c|c|}
\hline \multicolumn{1}{|c|}{ Jurusan } & $\begin{array}{c}\text { Rata-rata kehadiran } \\
\text { Mahasiswa }\end{array}$ & $\begin{array}{c}\text { Rata-rata Kehadiran } \\
\text { Dosen }\end{array}$ & $\begin{array}{c}\text { Rata-rata Kehadiran Mahasiswa } \\
\text { terhadap rata-rata Kehadiran Dosen }\end{array}$ \\
\hline Manajemen & 6 & 9 & $66,7 \%$ \\
\hline Akuntansi & 6 & 9 & $66,7 \%$ \\
\hline IESP & 5 & 8 & $62,5 \%$ \\
\hline
\end{tabular}

Sumber : Bag. Pengajaran FE-UII semester ganjil 2003/2004

Dari data pada tabel 9, rata-rata kehadiran mahasiswa terhadap kehadiran dosen berada pada kisaran 50\%-75\% yang menunjukkan bahwa persentase kehadiran mahasiswa FE-UII tidak terlalu tinggi (diatas $75 \%$ ). Untuk jurusan IESP, walaupun hasil penelitian menunjukkan sebagian besar mahasiswa $(53,9 \%)$ memiliki tingkat motivasi rendah, namun kenya- 
taannya, angka kehadiran mahasiswa IESP juga berada pada kisaran 50\%$75 \%$. Sehingga, jika dikaitkan dengan hasil penelitian tentang motivasi kehadiran mahasiswa, secara keseluruhan, terdapat sebuah kesesuaian hasil antara motivasi kehadiran mahasiswa dengan angka kehadiran mahasiswa sesungguhnya.

\section{KESIMPULAN DAN SARAN}

Dengan menggunakan model teori perngharapan Lawler, motivasi kehadiran mahasiswa FE-UII sebenarnya berada pada tingkatan yang relatif wajar. Hal ini terlihat dari angka motivation force mahasiswa FE-UII yang berada hanya pada tiga kelas teratas (tabel 2.9), yaitu: Kelompok dengan motivasi kehadiran rendah $(26,7 \%)$, kelompok dengan motivasi kehadiran sedang $(69,9 \%)$ dan kelompok dengan motivasi kehadiran tinggi $(3,4 \%)$. Dari hasil penelitian yang dilakukan, tidak ada satupun mahasiswa FE-UII yang berada pada kelompok tidak termotivasi untuk hadir dan kelompok kurang termotivasi untuk hadir.

Variabel effort $\rightarrow$ attendance merupakan variabel yang paling dominan mempengaruhi tingkat motivasi mahasiswa FE-UII. Karenanya, pihak fakultas harus menemukan kebijakan yang mampu meningkatkan "actual situation" mahasiswa FE-UII untuk menghadiri perkuliahan

Hipotesa kedua dari penelitian ini yang menduga terdapat perbedaan motivasi kehadiran mahasiswa FE-UII berdasarkan pada jurusan (prodi) terbukti. Dengan salah satu analisis non-parametrik chi square, dengan menyilangkan prodi mahasiswa pada baris dan tingkat motivasi pada kolom tabel kontigensi, diperoleh angka chi square sebesar 0,006. Pada tingkat signifikansi 5\%, hipotesa kedua tersebut diterima dengan perbedaan nyata terlihat pada motivasi kehadiran mahasiswa prodi IESP yang cenderung lebih rendah dibanding mahasiswa prodi manajemen dan akuntansi.

Dari penelitian mengenai motivasi kehadiran mahasiswa memang diperoleh hasil yang relatif positif mengenai masalah kehadiran mahasiswa, namun hanya sedikit sekali mahasiswa yang memiliki angka motivasi kehadiran yang sangat tinggi. Kelompok mahasiswa yang memiliki motivasi kehadiran tinggi sangat potensial untuk menjadi kelompok motivasi sangat tinggi. Beberapa kebijakan yang dapat dijadikan pertimbangan bagi FE-UII adalah:

1. Menyediakan sarana transportasi (Bus) khusus mahasiswa FE-UII. Ketersediaan sarana transportasi akan menjadi faktor yang dapat meningkatkan peluang mahasiswa untuk hadir. Tidak semua, mahasiswa FE-UII tinggal berdekatan dengan kampus. Sementara jalur bus yang melewati kawasan condong catur juga sangat terbatas. 
2. Menyempurnakan kondisi ruang belajar FE-UII

Jika dibandingkan dengan beberapa universitas lain, ruangan FE-UII sebenarnya lebih kondusif untuk belajar. Namun, mengingat besarnya harapan mahasiswa mengenai ruangan belajar yang kondusif membuat hal ini menjadi perhatian khusus.

\section{DAFTAR PUSTAKA}

Cooper \& Emory (terjemahan) (1995). Metode Penelitian Bisnis jilid 1. Edisi Kelima. Jakarta: Erlangga.

_. (terjemahan) (1995). Metode Penelitian Bisnis jilid II. Edisi Kelima. Jakarta: Erlangga.

Faqih, Aunur Rahim dan Munthoha (editor) (2002). Pemikiran dan Peradaban Islam. Edisi kedua. Yogyakarta: UII Press

Gibson, Ivancevich \& Donnelly (terjemahan) (1996). Organisasi. Edisi kedelapan, Jakarta : Binarupa Aksara

Hasibuan, Malayu (1996). Organisasi dan Motivasi. Jakarta : Bumi Aksara

Kanungo \& Mendoca (1992). Compensation: Effective Rewards Management. Toronto and Vancouver : Butterworth

Koentjoroe (2003). Metode Triangulasi: Sebuah pendekatan holistic dalam memahami phenomena sosial dan konstruksi psikologis, Makalah pada Kursus Metodologi Penelitian Dosen Muda di Lingkungan FE-UII tahun 2003. Paper di presentasikan pada diklat Metodologi Penelitian, 25 \& 26 April 2003, Fisipol UGM, Yogyakarta.

Maslow. A.H. (1943). "A Theory of Human Motivation". dalam Boone \& Bowen (editor) (1987). The Great Writtings in Management and Organizational Behaviour. HIm. 106 -122. New York: Random House Inc.

Mustafa, Zaenal (1990). Pengantar Statistik Terapan untuk Ekonomi. Yogyakarta : BPFE-UII

Nadler, D.A dan Lawler, E.A.(1977) "Motivasi: Suatu Pendekatan Diagnostik". dalam Usmara, Antonina (editor) (2003). Handbook of Organization, Kajian dan Teori Organisasi. HIm 13-33. Yogyakarta: Amara Books

Rikayanti, Lenny (1997). Analisis Kepuasan Kerja dan Pengaruhnya terhadap Jumlah Absensi Karyawan di RSU PKU Muhamadiyah Yogyakarta. Skripsi FE-UII : tidak dipublikasikan. 
Santoso, Singgih (2001). Buku Latihan SPSS Statistik Parametrik. Cetakan kedua. Jakarta: Elex Media Komputindo (2001). Buku Latihan SPSS Statistik Non-Parametrik. Jakarta : Elex Media Komputindo.

1 (2001). SPSS ver. 10 Mengolah Data Secara Profesional. Jakarta: Elex Media Komputindo.

Siagian, Sondang (1989). Teori motivasi dan Aplikasinya. Jakarta: CV. Rineka Cipta

Sobirin, Achmad (1999). "Memahami Arti dan Makna Budaya Organisasi". Sinergi. Vol.2., No.2, $189-215$.

Steers, R.M dan Rhodes, S.R. (1991). "Pengaruh Utama dari Kehadiran Karyawan: Suatu Model Proses". dalam Usmara, Antonina (editor) (2003). Handbook of Organization, Kajian dan Teori Organisasi. HIm 49-72. Yogyakarta : Amara Books

Suhartini \& Hudayati. (1993). Motivasi Mahasiswa dalam Memilih Tempat Tinggal, Studi Kasus pada FE-UII. Penelitian. FE-UII. Yogyakarta Tidak dipublikasikan.

Tim Penyusun Katalog Universitas Islam Indonesia (2000). Katalog 2000 Universitas Islam Indonesia. Edisi Revisi. Yogyakarta, UII Press.

Umar, Hussein (1998). Riset Sumber Daya Manusia dalam Organisasi. Edisi Revisi. Jakarta : Gramedia Pustaka Utama. 